Proc. Estonian Acad. Sci. Eng., 2006, 12, 4, 399-407

\title{
Application of the continuous indentation test method for the characterization of mechanical properties of $\mathrm{B}_{4} \mathrm{C} / \mathrm{Al}$ composites
}

\author{
Eduard Kimmari and Lembit Kommel
}

\begin{abstract}
Department of Materials Engineering, Tallinn University of Technology, Ehitajate tee 5, 19086 Tallinn, Estonia; eduard.kimmari@ttu.ee

Received 2 June 2006

Abstract. The principal aim of the present study was to apply the continuous instrumented indentation testing with the Oliver-Pharr method for analysing the load-depth data in determination of mechanical properties of boron carbide/aluminium composites. The indentation tests were carried out at different applied load values (from 10 to $100 \mathrm{~N}$ ) using Zwick 2.5/TS1S machine and a Vickers indenter. The hardness and reduced elastic modulus of composites were estimated from the unloading part of the indentation curve. The Vickers hardness numbers were compared with those obtained using conventional indentation, performed with Indentec 5030 SKV hardness tester.
\end{abstract}

Key words: boron carbide/aluminium composite, instrumented indentation, hardness, indentation elasticity modulus, Oliver-Pharr method.

\section{INTRODUCTION}

Boron carbide is one of the most important non-metallic hard materials with outstanding properties such as extremely high hardness (9.5 Mohs scale), excellent hot strength, remarkable corrosion resistance, very low specific gravity $\left(2.52 \mathrm{~g} / \mathrm{cm}^{3}\right)$ and high elastic modulus $\left[{ }^{1}\right]$. The extreme sensitivity to brittle fracture $\left(K_{1 \mathrm{c}}=3.7 \mathrm{MPa} \cdot \mathrm{m}^{1 / 2}\right)$ and difficulties of fabricating fully dense microstructures are the major limitations of $\mathrm{B}_{4} \mathrm{C}^{1}\left[{ }^{1}\right]$. The experiments $\left[{ }^{1-3}\right]$ have shown that introduction of the metal phase permits to overcome these limitations.

Considerable research on multiphase metal-ceramic materials, based on boron carbide $\mathrm{B}_{4} \mathrm{C}$, has been devoted to composites obtained by traditional methods of powder metallurgy $\left[{ }^{4-7}\right]$. The present study is focused on the $\mathrm{B}_{4} \mathrm{C} / \mathrm{Al}$ composites, synthesized by self-propagating high-temperature synthesis (SHS), whose properties were formed by heat treatment. 
Knowledge of detailed phase relations between $\mathrm{B}_{4} \mathrm{C}$ and $\mathrm{Al}$ at different temperatures is required for efficient material design. Investigations, performed in the field of the $\mathrm{B}_{4} \mathrm{C}-\mathrm{Al}$ interface chemistry, suggest that boron carbide reacts strongly with aluminium, resulting in a variety of binary and ternary compounds $\left[{ }^{1,4,8-11}\right]$.

Continuous instrumented indentation technique (IIT) was used to characterize mechanical properties of investigated materials. The technique most frequently employed measures the hardness $H$ and elastic modulus $E$. Methods have also been developed for evaluating the fracture toughness, the yield-stress and strainhardening characteristics and time-dependent properties such as viscoelasticity and creep $\left[{ }^{12}\right]$. Several methods have been developed to determine $H$ and $E$ from the indentation load/depth data $\left[{ }^{13-16}\right]$.

In this paper, the approach developed by Oliver and Pharr was used to determine the hardness and reduced modulus of indentation of $\mathrm{B}_{4} \mathrm{C} / \mathrm{Al}$ composites.

\section{EXPERIMENTAL}

Boron carbide powder and aluminium powder ASD-4 were used as initial materials for the synthesis of the composites. The initial boron carbide powder contained also free graphite $\mathrm{C}$. The fine grained $\mathrm{B}_{4} \mathrm{C}$ powder (mean grain size $1.24 \mu \mathrm{m}$ ) was obtained by attrition milling of the coarse-grained (mean grain size $17.3 \mu \mathrm{m})$ powder during $6 \mathrm{~h}$.

Self-propagating high-temperature synthesis (SHS) with followed pressing (about $150 \mathrm{MPa}$ ) was used to prepare the samples of $\mathrm{B}_{4} \mathrm{C} / \mathrm{Al}$ composites. The assynthesized composites were subjected to the heat treatment at different temperatures for microstructural development. The temperature of heat treatment varied in the range of $700-1470^{\circ} \mathrm{C}$. Table 1 summarizes the materials used in this study.

Table 1. Characterization of the materials

\begin{tabular}{l|c|ll}
\hline Sample & $\begin{array}{c}\mathrm{B}_{4} \mathrm{C}: \mathrm{Al}, \\
\mathrm{wt} \%\end{array}$ & \multicolumn{1}{c}{ Preparation } & \multicolumn{1}{c}{ Processing } \\
\hline N1 & $33.3: 66.7$ & $\mathrm{~B}_{4} \mathrm{C}(1.24 \mu \mathrm{m})+\mathrm{Al}$, attrition mixing 1 h & \multicolumn{1}{c}{ as-synthesized } \\
N2 & $33.3: 66.7$ & $\mathrm{~B}_{4} \mathrm{C}(1.24 \mu \mathrm{m})+\mathrm{Al}$, attrition mixing 1 h & $\mathrm{HT}^{*} 700^{\circ} \mathrm{C}$ \\
N3 & $33.3: 66.7$ & $\mathrm{~B}_{4} \mathrm{C}(1.24 \mu \mathrm{m})+\mathrm{Al}$, attrition mixing 1 h & $\mathrm{HT}^{*} 1275^{\circ} \mathrm{C}$ \\
N4 & $50: 50$ & $\mathrm{~B}_{4} \mathrm{C}(17.3 \mu \mathrm{m})+\mathrm{Al}$, hand mixing & as-synthesized \\
N5 & $50: 50$ & $\mathrm{~B}_{4} \mathrm{C}(17.3 \mu \mathrm{m})+\mathrm{Al}$, hand mixing & $\mathrm{HT}^{*} 700^{\circ} \mathrm{C}$ \\
N6 & $50: 50$ & $\mathrm{~B}_{4} \mathrm{C}(1.24 \mu \mathrm{m})+\mathrm{Al}$, attrition mixing $3 \mathrm{~h}$ & $\mathrm{HT}^{*} 1150^{\circ} \mathrm{C}$ \\
N7 & $50: 50$ & $\mathrm{~B}_{4} \mathrm{C}(1.24 \mu \mathrm{m})+\mathrm{Al}$, attrition mixing 1 h & $\mathrm{HT}^{*} 1080^{\circ} \mathrm{C}$ \\
N8 & $50: 50$ & $\mathrm{~B}_{4} \mathrm{C}(1.24 \mu \mathrm{m})+\mathrm{Al}$, attrition mixing 1 h & $\mathrm{HT}^{*} 1470^{\circ} \mathrm{C}$
\end{tabular}

* HT - heat treatment. 
The samples for IIT experiments were mechanically polished with $1 \mu \mathrm{m}$ diamond paste and prepared at the constant temperature $23^{\circ} \mathrm{C}$ during $5 \mathrm{~h}$. Mechanical properties of the $\mathrm{B}_{4} \mathrm{C} / \mathrm{Al}$ composites were studied with IIT that was realized by applying the load with an indenter and analysing the load-depth dependence data. Zwick 2.5/TS1S indentation machine and Vickers indenter were used for the IIT tests according to the standard EN ISO 14577-1. The indentation tests were carried out in a macrohardness region at different nominal load values $10,25,50,75$ and $100 \mathrm{~N}$ at constant loading/unloading rate $0.1 \mathrm{~N} / \mathrm{s}$ (speed at the point of contact $0.01 \mathrm{~mm} / \mathrm{s}$ ). Dwell time of $7.5 \mathrm{~s}$ was imposed for each indentation. Vickers hardness was also measured by conventional indentation tests with Indentec $5030 \mathrm{SKV}$ at $2.5 \mathrm{kgf}$.

\section{METHODOLOGY}

The hardness and elastic modulus of $\mathrm{B}_{4} \mathrm{C} / \mathrm{Al}$ composites were obtained from indentation curves. The load $P$ and the indentation depth $h$ were continuously measured during the test. Figure 1 shows the load-displacement (indentation depth) curve along with some important parameters used in the Oliver-Pharr analysis.

Important quantities are the peak load $\left(P_{\max }\right)$, the maximum depth or total surface deflection $\left(h_{\max }\right)$, the final or residual depth after complete unloading $\left(h_{\mathrm{f}}\right)$, the contact depth $\left(h_{\mathrm{c}}\right)$ at the maximum load and the slope of the upper portion of the unloading curve $(S=\mathrm{d} P / \mathrm{d} h)$. The parameter $S$ is known as the elastic contact stiffness and it yields information about the state of contact at the current point $\left[{ }^{12}\right]$.

An accurate measurement of the elastic contact stiffness $S$ and of the projected contact area $A_{p}$ under load must be performed to calculate the hardness and elastic modulus from the IIT test. The most widely used method for

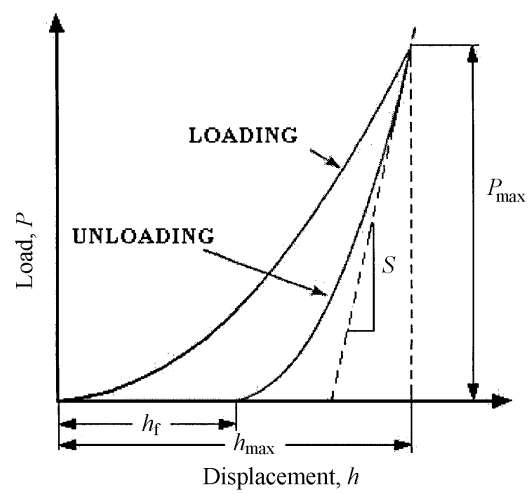

(a)

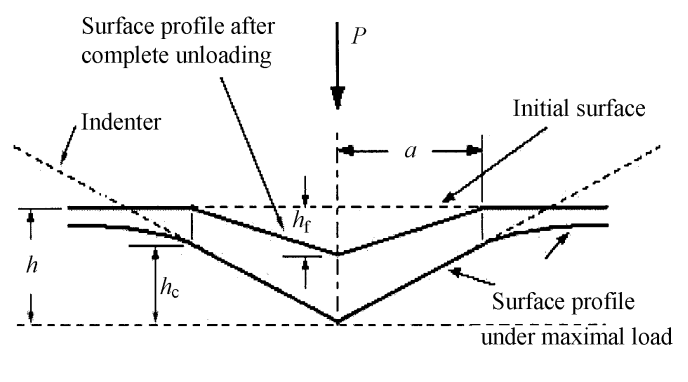

(b)

Fig. 1. A typical load-displacement curve (a) and schematic of a cross-section of an indentation (b). 
establishing the contact area was developed by Oliver and Pharr $\left[{ }^{12}\right]$. The OliverPharr method uses a power law to fit the unloading curve and takes the tangent at peak load $\left(P_{\max }\right)$ as the maximum contact stiffness $S_{\max }$ or the total system stiffness $\left[{ }^{17}\right]$. The projected contact area $A_{p}$, calculated using $S$, should be the actual contact area at the peak load. Extrapolating this line down to $P=0$ yields a displacement value $h_{\mathrm{c}}-$ the contact depth associated with the peak load $\left[{ }^{18}\right]$.

Using Sneddon's elasticity theory and empirical results of Oliver and Pharr, the contact depth $h_{\mathrm{c}}$ can be calculated as $\left[{ }^{19}\right]$ :

$$
h_{\mathrm{c}}=h_{\max }-\varepsilon \frac{P_{\max }}{S},
$$

where $\varepsilon=0.75$ is a function of the particular tip geometry (for the Vickers indenter).

In the Oliver-Pharr method, the data taken from the upper portion of the unloading curve is fitted with the power law relation

$$
P=\alpha\left(h-h_{\mathrm{f}}\right)^{m},
$$

where $m$ and $\alpha$ are empirical constants, determined after unloading data fitting and $h_{\mathrm{f}}$ is the residual depth. The fittings correspond to $80 \%$ of the unloading data. The R-squared values for all plots in the present study were $\mathrm{R}^{2}>0.99$.

When the fitting parameters $\alpha$ and $m$ are determined, the residual depth $h_{\mathrm{f}}$ can be evaluated by substitution $h=h_{\max }$ and $P=P_{\max }$ in Eq. (2):

$$
h_{\mathrm{f}}=h-\left(\frac{P}{\alpha}\right)^{\frac{1}{m}} \text {. }
$$

Now the contact stiffness is obtained from Eq. (2) differentiating $P$ with respect to $h$ :

$$
S=d P / d h=m \alpha\left(h_{\max }-h_{\mathrm{f}}\right)^{m-1} .
$$

Ideal area function of the indenter was used to calculate the real projected contact area $A_{\mathrm{p}}\left(A_{\mathrm{p}}=24.5 h_{\mathrm{c}}^{2}\right)$ at the peak load. For an ideal Vickers indenter, the projected area equals $A_{\mathrm{p}}$ at the given load $P$. The projected contact area $A_{\mathrm{p}}$ is the cross-sectional area of the indenter tip at a distance $h_{\mathrm{c}}$ from the tip apex.

When the contact stiffness $S$ and the projected contact area $A_{\mathrm{p}}$ are known, the reduced modulus of indentation $E_{\mathrm{r}}$ can be determined as

$$
E_{\mathrm{r}}=\frac{\sqrt{\pi}}{2 \beta} \frac{S}{\sqrt{A_{\mathrm{P}}}},
$$

where $\beta$ is a correction factor related to the lack of symmetry of the indenter, introduced by King $\left[{ }^{18}\right] ; \beta=1.0124$ for Vickers indenter. 
Indentation hardness $H_{\mathrm{IT}}$ or the so-called Meyer hardness is defined as the test force $P$ divided by the projected area of contact $A_{\mathrm{p}}\left[{ }^{20}\right]$ :

$$
H_{\mathrm{IT}}=P / A_{\mathrm{p}} \text {. }
$$

Vickers hardness $H V$ can be determined as

$$
H V=P / A_{\mathrm{s}},
$$

where

$$
A_{\mathrm{s}}=\frac{d^{2}}{1.854368}
$$

is the surface of the contact area.

The projected contact area $A_{\mathrm{p}}$ can be expressed as a function of the diagonal of the impression $\left[{ }^{18}\right]$ :

$$
A_{\mathrm{p}}=0.5 d^{2}
$$

The value of the diagonal $d$ can be expressed as

$$
d=\sqrt{2 A_{\mathrm{p}}}=\frac{S}{\beta E_{\mathrm{r}}} \sqrt{\frac{\pi}{2}}
$$

\section{RESULTS AND DISCUSSION}

Figure 2 shows the variations of indentation hardness $H_{\mathrm{IT}}$ and reduced modulus $E_{\mathrm{r}}$ with indentation load estimated by the Oliver-Pharr method for the samples of $\mathrm{B}_{4} \mathrm{C} / \mathrm{Al}$ composites.

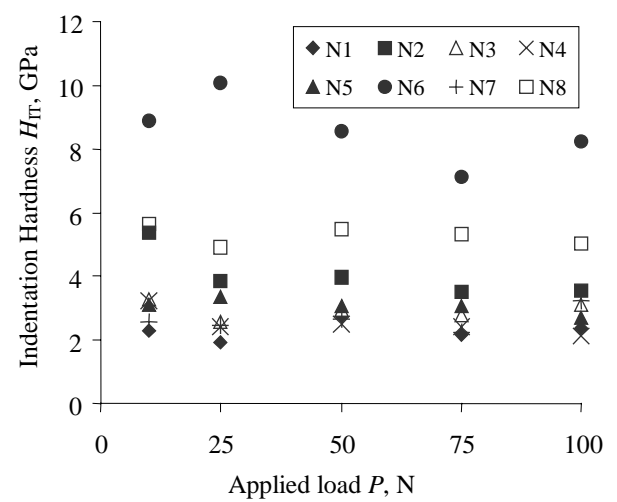

(a)

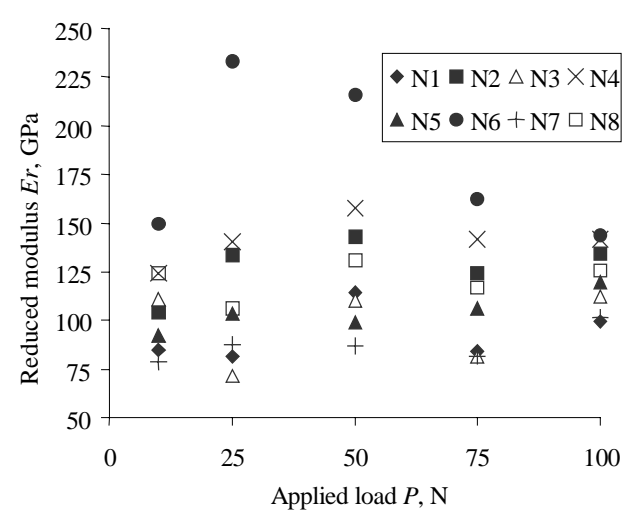

(b)

Fig. 2. Variation of the indentation hardness (a) and of the reduced modulus (b) with the indentation load. 
Most materials exhibit a strong indentation size effect (ISE), i.e. the hardness of the material varies with the indentation load. As load increases, hardness usually decreases until a constant hardness plateau is reached $\left[{ }^{21}\right]$. Three regions of Vickers hardness testing conditions for metals and single crystals have been defined by Buckle: microhardness ( $<200$ gf), low-load hardness ( $200 \mathrm{gf}-2 \mathrm{kgf}$ ) and normal hardness ( $>2 \mathrm{kgf}$ ). The ISE for these types of materials becomes apparent only at low-load conditions $\left[{ }^{22}\right]$.

Figure 2 shows that Vickers hardness for six samples is maximal at the lowest applied load $(10 \mathrm{~N})$. The higher the hardness of the material the more it varies with the applied load. The indentation hardness number diminishes with increasing indentation load from 10 to $100 \mathrm{~N}$, but its variations for the samples $\mathrm{N} 1, \mathrm{~N} 3, \mathrm{~N} 4, \mathrm{~N} 5$ and $\mathrm{N} 7$ are in the range of statistical uncertainty. Therefore it is necessary to investigate the hardness-load and modulus-load dependencies over a wider range of the applied indentation load.

Another phenomenon, affecting indentation results, is microcracking around the impression on the surface and subsurface when the applied load is high enough $\left[{ }^{22}\right]$. Since the microfracture occurs mainly during the loading, a portion of the energy, used to create the deformation, is dissipated by the crack formation. Thus it is expected that the hardness, measured with a cracking indentation, will be higher than that measured with a crack-free indentation $\left[{ }^{22}\right]$. No microcracking was observed in the range of $10-100 \mathrm{~N}$ in the samples of the assynthesized material (N1 and N4) and in the sample N5. In other samples the microcracks were observed at the load value $25 \mathrm{~N}$ and higher.

Pile-up is the most important plastic phenomenon, where the material plastically uplifts around the contact impression $\left[{ }^{12}\right]$. The pile-up behaviour at the indentation depends on the work hardening of the material as well as on the ratio of the yield stress to the Young modulus $\left(\sigma_{\mathrm{y}} / E\right)$. Another important parameter, estimated directly from continuous IIT, is the ratio of the final indentation depth to the depth at peak load, $h_{\mathrm{f}} / h_{\max }$. Bolshakov and Pharr $\left[{ }^{23}\right]$ have shown that there is a strong correlation between $\sigma_{\mathrm{y}} / E$ and $h_{\mathrm{f}} / h_{\max }$. The pile-up is large when $h_{\mathrm{f}} / h_{\max } \approx 1$; when $h_{\mathrm{f}} / h_{\max }<0.7$, very little pile-up occurs $\left[{ }^{23}\right]$. The Oliver-Pharr method is based on an elastic analysis, which can account for sink-in only. Therefore the method gives a good estimate of the real indentation contact area (the hardness and elastic modulus) only when $h_{\mathrm{f}} / h_{\max }<0.7$, independent of the work hardening behaviour. The work hardening characteristic of the material must be taken into account when $h_{\mathrm{f}} / h_{\max }>0.7$.

The ratio $h_{\mathrm{f}} / h_{\max }$ varied in the range of $0.64-0.88$ at different indentation loads. The highest values of $h_{\mathrm{f}} / h_{\max }$ were obtained for the samples of assynthesized material N1 (0.83-0.85) and N4 (0.85-0.88), while the lowest - for the sample N6 (0.64-0.70). Since the ratios $h_{\mathrm{f}} / h_{\max }$ for investigated materials are close to the transition value of 0.7 , indentations were imaged by optical microscopy to examine the extent of the pile-up. There is no bowing-out of the sides of the residual impressions observed in the case of all samples, which 


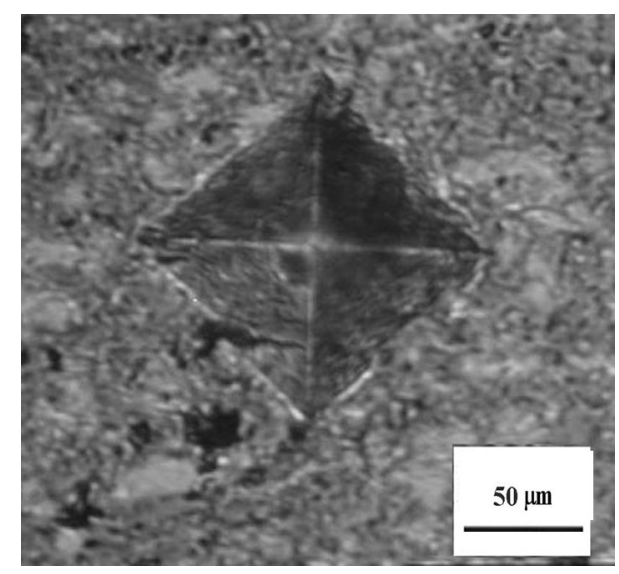

Fig. 3. Vickers indentation in sample N4.

suggests that the pile-up was insignificant. Figure 3 shows an impression of the Vickers indenter in the sample N4 with the highest value of $h_{\mathrm{f}} / h_{\max }$.

Table 2 compares the numbers of Vickers hardness, measured by conventional indentation testing with $2.5 \mathrm{kgf}$ with those estimated by the Oliver-Pharr approach.

The Vickers hardness numbers, determined by the Oliver-Pharr method and by conventional hardness measurement are in good agreement for the composites with the 50:50 wt\% proportion of initial components (samples N4, N5, N6 and $\mathrm{N} 8$ ), although the ratio $h_{\mathrm{f}} / h_{\max }$ for these materials is higher than 0.7 . For the samples N1, N3 and N7 the hardness, evaluated by the Oliver-Pharr method, is lower than the measured one. It can be explained by different loading rate of the methods and, consequently, by different behaviour of the material during indentation. At low loading rates, indentation creep becomes important and that may result in a lower hardness number.

Table 2. Comparison of Vickers hardness number estimated by two methods

\begin{tabular}{c|cccc}
\hline Sample & $\begin{array}{c}\text { Vickers Hardness } \\
\text { using Indentec, } \\
H V 2.5\end{array}$ & $\begin{array}{c}\text { Vickers Hardness } \\
\text { using Oliver-Pharr } \\
\text { approach, load 25 N }\end{array}$ & $\begin{array}{c}h_{\mathrm{f}} / h_{\max } \\
\text { (at 25 N) }\end{array}$ \\
\hline N1 & $244 \pm 23$ & 177 & 0.84 \\
N2 & $211 \pm 16$ & 356 & 0.80 \\
N3 & $302 \pm 18$ & 251 & 0.78 \\
N4 & $197 \pm 10$ & 223 & 0.88 \\
N5 & $303 \pm 14$ & 308 & 0.81 \\
N6 & $845 \pm 38$ & 930 & 0.70 \\
N7 & $430 \pm 23$ & 227 & 0.78 \\
N8 & $447 \pm 23$ & 454 & 0.73
\end{tabular}




\section{CONCLUSIONS}

The IIT technique with the Oliver-Pharr method was used to determine the hardness and reduced elasticity modulus of $\mathrm{B}_{4} \mathrm{C} / \mathrm{Al}$ composites. The materials were tested at different indentation loads from 10 to $100 \mathrm{~N}$. Since the ratio of indentation depths $h_{\mathrm{f}} / h_{\max }$ is close to 0.7 , the use of the Oliver-Pharr approach must be accompanied by microstructural investigations with the analysis of the pile-up and work hardening behaviour. The composites should be tested in a wide range of indentation loads to estimate the transition from the loaddependent to load-independent hardness, which is related to the indentation brittleness of the material. Loading rate effect should be taken into account to adequately estimate mechanical properties of the composites.

\section{ACKNOWLEDGEMENT}

This work was supported by Estonian Science Foundation (grant No. 6163).

\section{REFERENCES}

1. Halverson, D. C. Processing of boron carbide-aluminum composites. J. Am. Ceram. Soc., 1989, 72, 775-780.

2. Kommel, L., Traksmaa, R. and Kimmari, E. Influence of binder composition and microhardness on wear properties of lightweight composites. Powder Metallurgy Progr., 2003, 3, $140-145$.

3. Kommel, L., Hussainova, I. and Kimmari, E. The structure and properties forming in boron carbide/aluminum composite during processing. In Proc. World Congress on Powder Metallurgy and Particulate Materials 2002. CD ISBN 1-878954-90-3.

4. Pyzik, A. J. and Beaman, D. R. Al-B-C phase development and effects on mechanical properties of $\mathrm{B}_{4} \mathrm{C} / \mathrm{Al}$ derived composites. J. Am. Ceram. Soc., 1995, 78, 305-312.

5. Zhang, H., Ramesh, K. T. and Chin, E. S. C. High strain rate response of aluminum $6092 / B_{4} C$ composites. Mat. Sci. Eng. A, 2004, 384, 26-34.

6. Kouzeli, M., San Marchi, C. and Mortensen, A. Effect of reaction on the tensile behavior of infiltrated boron carbide-aluminum composites. Mat. Sci. Eng. A, 2002, 384, 264-273.

7. Torquato, S., Yeong, L. Y., Rintoul, M. D., Milius, D. L. and Aksay, I. A. Elastic properties and structure of interpenetrating boron carbide/aluminum multiphase composites. J. Am. Ceram. Soc., 1999, 82, 1263-1268.

8. Viala, J. C. and Bouix, J. Chemical reactivity of aluminium with boron carbide. J. Mater. Sci., 1997, 32, 4559-4573.

9. Arslan, G., Kara, F. and Turan, S. Quantitative X-ray diffraction analysis of reactive infiltrated boron carbide-aluminium composites. J. Eur. Ceram. Soc., 2003, 23, 1243-1255.

10. Liu, C. H. Structure and properties of boron carbide with aluminum incorporation. Mater. Sci. Eng. B, 2000, 72, 23-26.

11. Rogl, P. and Bittermann, H. Ternary metal boron carbides. Int. J. Ref. Met. Hard Mater., 1999, 17, 27-32.

12. Hay, J. L. and Pharr, G. M. Instrumented indentation testing. In ASM Handbook, Vol. 8: Mechanical Testing and Evaluation, 10th ed. (Kuhn, H. and Medlin, D., eds.). ASM International, 2000, 232-243. 
13. Gubicza, J., Juhasz, A. and Lendvai, J. A new method for hardness determination from depth sensing indentation tests. J. Mater. Res., 1996, 11, 2964-2967.

14. Troyon, M. and Huang, L. Critical examination of the two-slope method in nanoindentation. J. Mater. Res., 2005, 20, 2194-2198.

15. Doerner, M. F. and Nix, W. D. A method for interpreting the data depth-sensing indentation instruments. J. Mater. Res., 1986, 1, 601-609.

16. Oliver, W. C. and Pharr, G. M. A new improved technique for determining hardness and elastic modulus using load and sensing indentation experiments. J. Mater. Res., 1992, 7, 1564 1582.

17. He, J. L. and Veprek, S. Finite element modeling of indentation into superhard coatings. Surf. Coat. Tech., 2003, 163-164, 374-379.

18. Franco, A. R., Pintaude, G., Sinatora, A., Pinedo, C. E. and Tschiptschin, A. P. The use of a vickers indenter in depth sensing indentation for measuring elastic modulus and vickers hardness. J. Mater. Res., 2004, 7, 483-491.

19. Chinh, N. Q., Gubicza, J., Kovacs, Z. and Lendvai, J. Depth-sensing indentation tests in studying plastic instabilities. J. Mater. Res., 2004, 19, 31-45.

20. Overview of mechanical testing standards. Applications Bulletin, CSM Instruments, 2002, No. 18.

21. Quinn, G. D., Patel, P. J. and Lloyd, I. Effect of loading rate upon conventional ceramic microindentation hardness. J. Res. Nat. Inst. Stand. Technol., 2002, 107, 299-306.

22. Gong, J., Wu, J. and Guan, Z. Examination of the indentation size effect in low-load Vickers hardness testing of ceramics. J. Eur. Ceram. Soc., 1999, 19, 2625-2631.

23. Bolshakov, A. and Pharr, G. M. Influences of pile-up on the measurement of mechanical properties by load and depth sensing indentation techniques. J. Mater. Res., 1998, 13, $1049-1058$.

\section{$B_{4}$ C/Al komposiitmaterjalide mehaaniliste omaduste määramine indenteerimismeetodiga}

\section{Eduard Kimmari ja Lembit Kommel}

Artikli eesmärgiks on boorkarbiid/alumiinium-komposiitmaterjalide mehaaniliste omaduste määramine indenteerimismeetodiga. Indenteerimiskatsed on teostatud indenteerimisjõu erinevatel suurustel $(10-100 \mathrm{~N})$, kasutades seadet Zwick 2.5/TS1S ja Vickersi indentorit. Kõvaduse ja elastsusmooduli väärtused on leitud, kasutades Oliveri-Pharri arvutusmetoodikat. Samuti on uuritud indenteerimisjõu mõju kõvaduse määramise tulemustele. Vickersi kõvaduse väärtusi on võrreldud mõoturi Indente SKV abil saadud tulemustega. 